https://helda.helsinki.fi

pÿSteve Watson, 14 June 195822 January 2016

\title{
Waterton, Emma
}

2016-04

pÿWaterton, E \& Thomas , S 2016 , ' Steve Watson, 14 June 195822 January 2016 ' , Journal of Community Archaeology and Heritage , vol. 3 , no. 2 , pp. 157-159 . https://doi.org/10.1080/20518196.201

http://hdl.handle.net/10138/300899

https://doi.org/10.1080/20518196.2016.1154721

acceptedVersion

Downloaded from Helda, University of Helsinki institutional repository.

This is an electronic reprint of the original article.

This reprint may differ from the original in pagination and typographic detail.

Please cite the original version. 


\section{OBITUARY}

Steve Watson, 14 June 1958-22 January 2016

\section{Emma Waterton \& Suzie Thomas}

To cite this article: Emma Waterton \& Suzie Thomas (2016) Steve Watson, 14 June 1958-22 January 2016, Journal of Community Archaeology \& Heritage, 3:2, 157-159, DOI: 10.1080/20518196.2016.1154721

To link to this article: https://doi.org/10.1080/20518196.2016.1154721

The unexpected death of Professor Steve Watson was a sudden and deeply saddening shock to heritage scholars on several continents, and to the many students that he taught in the U.K. and that he inspired elsewhere. He will be remembered for his immense and often agenda-setting contributions to the fields of heritage studies and heritage tourism.

After undertaking a BA in Social Studies at Liverpool Polytechnic (now Liverpool John Moores University), an MA in Social Administration (University of York) and an MPhil in Social Policy (also conferred by the University of York), Steve chose to complete a PhD in the Department of Archaeology, University of York, under the supervision of Professor Laurajane Smith. That decision proved instrumental for his ensuing career, as it was during his time as a doctoral student that Steve turned his focus to the field of heritage. His subsequent contributions to academia thus revolved around his interest in exploring the social, political and economic impacts of heritage, drawing on the politics of affect, semiotic theory and a deep interest in the links between academic study and everyday experiences with the past.

Perhaps his greatest passion, however, was a place he first visited some 30 years ago: Spain, particularly its Andalucian cities and towns, with their street markets, tapas bars, ruins and art galleries. He was enchanted especially by the city of Seville, which he often proclaimed to have captured his heart through its Golden Tower, the Giralda, the Sierpes, the Alcazar Real and the Plaza de Espana. He cultured academic links there also, developing an ongoing research relationship with colleagues at the University of Seville. His personal enthusiasm for Spain had a palpable influence on his intellectual curiosity, as did his abiding sense of privilege that what was, in many ways, his 'hobby', could form such a central part of his work, thereby enabling him to travel to, and frequently experience, the places and people of Spain. In addition to Seville, his work took him to Granada, Pamplona, San Sebastian, Bilbao, Cordoba and the Huelva province, where he was introduced to the Dolmen de Soto, which, in his words, was a 'must see' attraction in a wonderful place.

While this passion became explicitly nestled within a long-term project exploring the history of Spanish travel-writers and their expressions of Spain as something felt and experienced through all the senses, it also provided agreeable writing and development conditions for a large proportion of Steve's other outputs: the invitational emails to contributors to the Palgrave Handbook for Contemporary Heritage Research (2015) were sent from the foyer of Hotel San Sebastian; the nuts and bolts of the paper, 'Framing Theory: Towards a Critical Imagination in Heritage Studies' (2013), were crafted in a café located by a Spanish bridge while a nearby waitress fought off a huge hornet; and countless ideas were germinated with the help of a glass (or two) of barrel-fermented Spanish white Rioja, furnished with a chilling ice cube. 
Aside from his focus on Spain, Steve's work was primarily linked with theoretical explorations of community engagement, the visuality of the past, the affective dimensions of heritage and encounters with heritage tourism. His interest in the latter had been piqued as a child, he would recall, at Filey Butlins in 1963, or Sunday School trips to Redcar. He undertook work on one or a combination of those themes in Cordoba (Spain), Towton (U.K.), Oxford (U.K.), Rhodes (Greece), Nether Poppleton (U.K.) and Seville (Spain). There were, of course, other things with which Steve was linked; he regularly claimed a likeness for Michael Caine and worked hard at finessing a vocal fidelity with the actor; he was thrilled when, in Sydney, he was approached by a local passerby who hoped he might be (then) Prime Minister Kevin Rudd; and he was keen to regularly point out his skills and value as a 'qualified life coach'.

Quite aside from Steve's immense intellectual contributions in terms of teaching, writing and practice, all of which were marked by a profound engagement with social and cultural theory, he was also distinguished by a combination of remarkably rewarding personal qualities: he was generous, supportive, warm and genuine; he had a remarkable capacity for friendship; he had a wonderful sense of fun; he had a wonderfully wry sense of humour, which he wielded with utmost care; and he went to great lengths to help improve the wellbeing of his colleagues and foster collegiality. This was evident in 2015 when, on a visit to the University of Helsinki in Finland, he inspired not only university staff and students, but also heritage professionals working in the Finnish Forestry agency Metsähallitus, with his deep insights, willingness to share ideas, and kind, approachable attitude. In a workshop on academic publishing for doctoral students, he reminded his audience that academics are first and foremost writers, and to remember to arrange the other duties around this most important task - not the other way round. After his final lecture in Helsinki, in which he talked about the interactions between materiality and representation, expectation and experience and the affective and cognitive, in a fascinating paper entitled 'The Castle Imagined', one distinguished Finnish scholar turned to a colleague and said simply, 'he's excellent'. All had hoped that this first visit would not have been his last to Finland, and as was typical of Steve's energy and enthusiasm, many a project idea sprung up from that all too brief encounter.

The Journal of Community Archaeology and Heritage team particularly remember Steve for his kind support and friendship in reaching out to offer advice to us during the early stages of the journal's development sharing insight from his own editorial experiences with the International Journal of Heritage Studies and Enlightening Tourism. A Pathmaking Journal. He was extremely positive about the journal, appreciating its potential and seeing its place in the debates around community engagements with cultural heritage of all kinds. He gladly took on the role of peer reviewer when asked, and clearly understood exactly what the journal was about. He also had an excellent idea for a future article. It is a particular sadness that, although planned for some time, we had not yet formally invited Steve to join our Editorial Board.

His self-effacing approach to his own work, coupled with his limitless support for others, will no doubt influence the next generation of scholars in the field of heritage in the most positive of ways. He was one of heritage studies' finest minds and easily one of the field's most inspiring characters.

\section{Selected publications}

Waterton, Emma, and Steve Watson, eds. 2015. The Palgrave Companion to Contemporary Heritage Research. London: Palgrave.

Watson, Steve. 2015. "Ethics and Heritage Tourism." In The Ethics of Cultural Heritage, edited by Tracey Ireland and John Schofield, 33-51. New York: Springer.

Waterton, Emma, and Steve Watson, eds. 2014. The Semiotics of Heritage Tourism. Bristol: Channel View. 
Watson, Steve, 2014. "Making Spain: The Spanish Imaginary in Travel Writing since the Second World War." In Travel and Imagination, edited by Garth Lean, Russell Staiff, and Emma Waterton, 119-135. Farnham: Ashgate.

Smith, Laurajane, Emma Waterton, and Steve Watson, eds. 2012. The Cultural Moment in Heritage Tourism. London: Routledge.

Waterton, Emma, and Steve Watson, eds. 2010. Heritage and Community Engagement: Collaboration or Contestation? London: Routledge.

Waterton, Emma, and Steve Watson, eds. 2010. Culture, Heritage and Representations. Aldershot: Ashgate.

Watson, Steve, 2001. "Touring the Medieval: Tourism, Heritage and Medievalism in Northumbria." Studies in Medievalism 11: 239-261.

Hodges, Andrew, and Steve Watson. 2000. "Community-based Heritage Management: A Case Study and Agenda for Research." International Journal of Heritage Studies 6 (3): 231-243.

\section{EMMA WATERTON}

Western Sydney University, Australia

Email: e.waterton@westernsydney.edu.au

\section{SUZIE THOMAS}

University of Helsinki, Finland

Email: suzie.e.thomas@helsinki.fi 